\title{
Opportunistic microflora at unusual sites: marker pathogens in severe posttrans- plant immune deficiency
}

\author{
Alexey B. Chukhlovin ${ }^{1}$, Olga S. Pankratova ${ }^{2}$ \\ ${ }^{1}$ R. Gorbacheva Memorial Research Institute of Children Oncology, Hematology and Transplantology, The First St. Petersburg State \\ I. Pavlov Medical University, St. Petersburg, Russia \\ ${ }^{2}$ Tampere University Hospital, Tampere, Finland
}

Prof. Alexey B. Chukhlovin, R. Gorbacheva Memorial Research Institute of Children Oncology, Hematology and Transplantology, The First St. Petersburg State I. Pavlov Medical University, L. Tolstoy St. 6-8, 197022, St. Petersburg, Russia
Phone: $+7(812) 3386052$

E-mail: alexey.chukh@mail.ru

\section{Summary}

Early severe immune suppression occurs after cytoreductive cancer treatment, especially, following conditioning therapy and hematopoietic stem cell transplantation (HSCT). Posttransplant recovery of immune response proceeds slowly, in particular, for the lymphocyte subsets. At later terms, immunosuppressive drugs promote the immune deficiency state. Therefore, HSCT is associated with activation of different endogenous infections. In most instances, the infectious complications are caused by opportunistic microorganisms (bacteria, fungi and viruses) which normally inhabit skin, mucosae etc. Their post-treatment proliferation and migration may occur to normally non-involved body areas (blood flow, bronchoalveolar areas, urinary pathways, skin dermal layers, lymph nodes, etc.). Hence, the early posttransplant activation of latent pathogens may be detected in peripheral blood, cerebrospinal fluid, bronchoalveolar lavage, saliva, urine and other samples being normally protected by immune system. The number of infectious species found in the same patient also correlates with higher posttransplant mortality.
Therefore, diagnostics of common immune deficiency markers after intensive cytoreductive chemotherapy could be combined with a search for opportunistic infections at the normally non-infected sites (peripheral blood, saliva, urine) as well as affected mucosal surfaces (sputum, bronchial secretions, cerebrospinal fluid). Several validated diagnostic panels (mostly multiplex PCR) were developed, in order to detect and assess number of infectious markers (viral, fungal and bacterial) in the patient. They could be applied for more specific evaluation of immune deficiency grade.

\section{Keywords}

Cytoreductive therapy, immune deficiency, bacteria, viruses, activation, expansion, multiple infections, marker microorganisms.

\section{Introduction}

Early infections caused by opportunistic microorganisms are quite common after allo-HSCT, thus requiring massive and expensive anti-infectious therapy. Massive cytoreductive therapy in cancer is followed by pronounced neutropenia and exhaustion of most lymphoid cell populations [1]. Hence, a total deficiency of immune response is evident since 1-2 weeks after conditioning therapy and HSCT.
The immune failure is characterized by exhaustion of specific humoral factors, e.g., serum immunoglobulins, and decreased counts of immune subpopulations (granulocytes, monocytes, T- and B cell subsets, NKs). These immune indexes reflect general drop and recovery of immune system which may continue for months and years [1]. However, these cellular and humoral markers alone cannot accurately predict clinical risk of local infections at epithelial and mucosal surfaces (pneumonia, cystitis, stomatitis et.). The most hazardous terms for development of bacterial, fungal 
and viral infections are shown in Fig. 1. Post-transplant deficiencies of certain leukocyte populations seem to correlate with viral, bacterial and fungal infections [2]. Hence, the immune failure may, in principle, assessed via detection of multiple microorganisms which normally live and grow on skin and external mucous surfaces (i.e., oral cavity, pharynx, urethral ways etc). These opportunistic pathogens are normally controlled by the host immune surveillance. However, within weeks after HSCT, they tend to colonize deeper sites and areas (e.g., respiratory ways, urogenital tract etc.) causing different affections of internal organs. Hence, posttransplant detection of microflora in bloodstream and, especially, at local inflammation sites reflects the degree of immune failure. Appropriate clinical experience was translated into numerous clinical recommendations based on empiric antibiotic treatment during early hematopoietic recovery and febrile neutropenia [3-6]. However, despite routine protection of the post-HSCT patients by broad-spectrum antibiotics, and antiviral treatment for a period of myelopoiesis reconstitution (up to 4 weeks), the rates of local post-transplant infections (e.g., pneumonia) may reach $25 \%$ of the HSCT patients [7].
Moreover, unusual sites of infection (typhlitis, perirectal infections and atypical forms of cellulitis) in neutropenic patients were noted decades ago [8]. About $60 \%$ of febrile neutropenia in early posttransplant period are classified as fever of unknown origin without distinct infectious pathogen, yet most respond to antibacterial therapy. Unusual sites of infection include typhlitis, perirectal infections and atypical forms of cellulitis.

Later on, a number of immunosuppressive drugs are routinely used after allogeneic HSCT (allo-HSCT) in order to prevent graft-versus-host disease (GvHD). In fact, some immune populations, especially, adaptive immunity cells, may recover at several months and years post-transplant $[1$, 9]. Hence, a long-term immune deficiency after HSCT is a chronic condition predisposing for opportunistic infections, fungal invasions and activation of endogenous viruses. Such infectious markers could be registered, and the co-infection rates may be used for assessing the grade of immune deficiency in the patient.

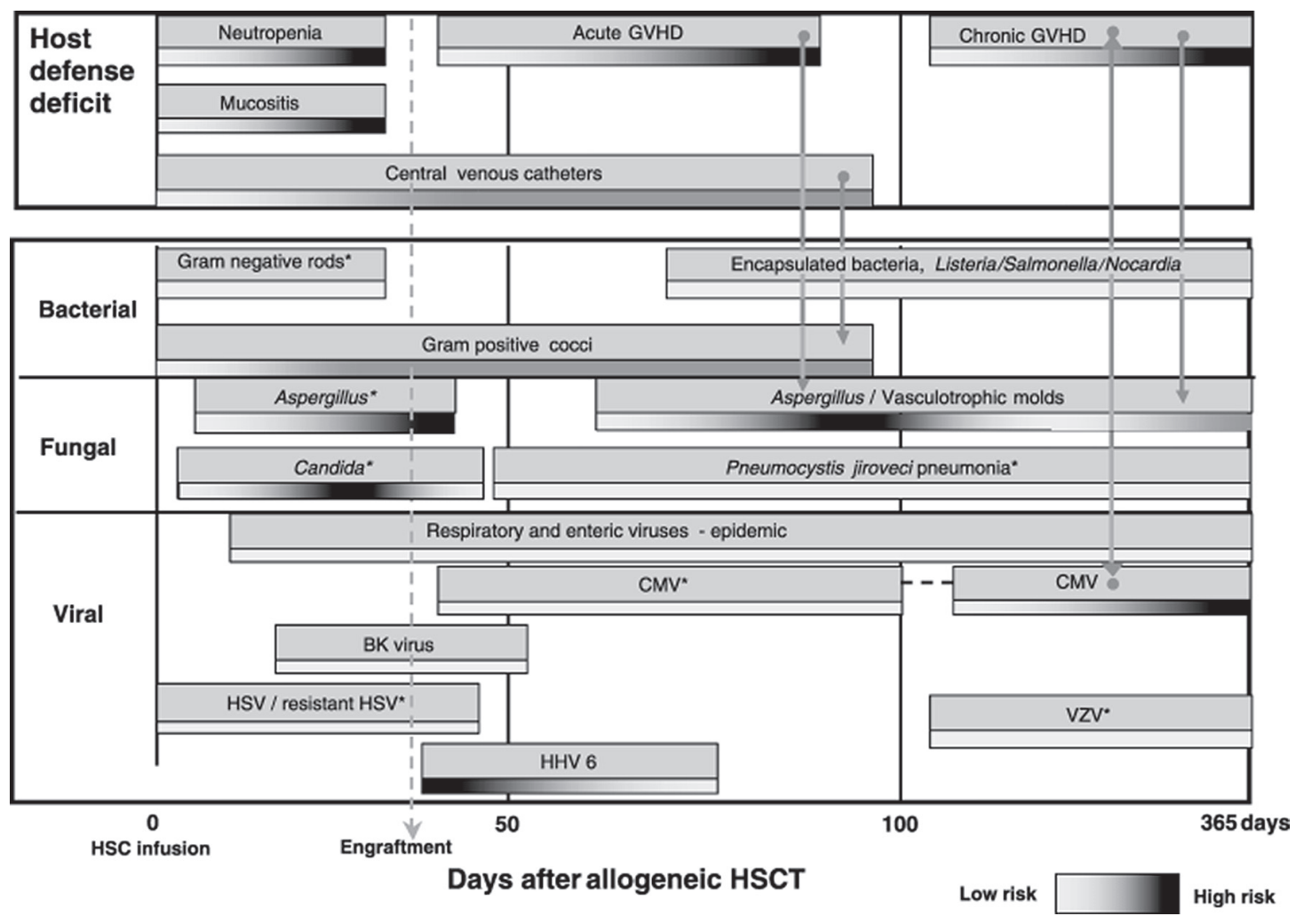

Figure. 1. Terms of the most common infectious complications in HSCT. [10] 
Severity and clinical significance of the post-HSCT immune deficiency depends on dosage and expected immunotoxic effects of drugs used in the conditioning protocol, i.e., myeloablative or nonmyeloablative regimen. However, individual damage to the patient's immune system is modified by the following factors:

- Intensity and number of preceding cytoreductive treatments exhausting the myelo-and lymphopoiesis system;

- Pharmacokinetics of cytotoxic drugs which strongly depends on its administration route, altered liver and kidney functions, and genetic variants affecting activation or inactivation of the given $\operatorname{drug}(\mathrm{s})$;

- Recipient/donor immune conflict, i.e., partial HLA mismatch, severe graft-versus-host disease [11].
Therefore, personalized evaluation of selected pathogen-specific markers, their multiplicity and biodiversity seems to be an efficient tool for specifying degree of immune deficiency observed at early and later terms post-transplant.

Hence, the aim of our review is to propose the sets (panels) of latent/opportunistic marker microorganisms as potential markers of immune deficiency, especially, in post-transplant patients. A number of species- and genus-specific multiplex PCR kits, as well as some integral microbial markers could be used for severity evaluation of immune deficiency when testing peripheral blood samples and locally infected sites.

Table 1. List of opportunistic flora activated in immunocompromised patients (combined of different studies)

\begin{tabular}{|c|c|c|c|c|}
\hline \multicolumn{5}{|c|}{ Predominant location sites in immunocompetent subjects } \\
\hline $\begin{array}{l}\text { Oral cavity/ } \\
\text { oropharynx }\end{array}$ & Skin/upper airways & Gut-associated & Urogenital & Lymph nodes, blood cells \\
\hline \multirow[t]{3}{*}{$\begin{array}{l}\text { Streptococcus } \\
\text { haemolyticus } \\
\text { Staphylococcispp. } \\
\text { M.avium } \\
\text { M.bovis }\end{array}$} & $\begin{array}{l}\text { Klebsiella pneumoniae; } \\
\text { Pseudomonas aeruginosa } \\
\text { Acinetobacter baumanni } \\
\text { Staph. Epidermidis } \\
\text { Staph. hominis } \\
\text { Coagulase-negative staph- } \\
\text { ylococci, } \\
\text { Staphylococcus aureus } \\
\text { Streptococcus pneumoniae, } \\
\text { Streptococcus pyogenes }\end{array}$ & $\begin{array}{l}\text { E.Coli } \\
\text { Salmonella } \\
\text { Enterobacter En- } \\
\text { terococcus faecalis } \\
\text { Enterococcus faecium } \\
\text { Stenotrophomonas } \\
\text { maltophilia } \\
\text { Clostridium difficile } \\
\text { Lactobacillus spp. } \\
\text { Toxoplasma gondii }\end{array}$ & $\begin{array}{l}\text { Proteus mirabilis } \\
\text { Cor. urealytica } \\
\text { Mycoplasma } \\
\text { hominis } \\
\text { Toxoplasma gondii }\end{array}$ & Bartonella spp. \\
\hline & $\begin{array}{l}\text { Candida spp } \\
\text { Malassezia } \\
\text { Aspergillus spp } \\
\text { Mucor spp } \\
\text { Pneumocystis jiroveci }\end{array}$ & & Candida spp & \\
\hline & $\begin{array}{l}\text { Herpes simplex virus } \\
\text { Varicella zoster virus }\end{array}$ & $\begin{array}{l}\text { Cytomegalovirus } \\
\text { Adenovirus }\end{array}$ & $\begin{array}{l}\text { Polyomavirus: } \\
\text { BK; JC }\end{array}$ & $\begin{array}{l}\text { Cytomegalovirus } \\
\text { Epstein-Barr virus } \\
\text { Adenovirus } \\
\text { Human T lymphocyte virus } \\
\text { type } 1\end{array}$ \\
\hline
\end{tabular}

\section{Incidence and sites of opportunistic infections}

The list of opportunistic infections in immunocompromised patients is rather broad, however, limited by distinct microbial, fungal and viral species (see Table 1).

Most bacterial species revealed in immunocompromised patients proved to be opportunistic microorganisms, i.e., those which are present in normal human skin or inhabit normal gut mucosa. The main prerequisites for growth and cytopathic/inflammatory effects of opportunistic flora are as follows:

(1) Penetrating skin barrier; (2) Passing mucosal surfaces;

(3) Remote dissemination via bloodstream to lymph nodes, spleen, liver, kidney, lungs; (4) Passing blood/brain barrier. As a result, posttransplant patients develop opportunistic infections of lower respiratory ways, brain, urinary tract, as well as deep abscesses caused by skin or intestinal microor- ganisms. Moreover, the skin microorganisms may colonize catheter lumen, then proceeding into a bloodstream infection.

\section{Incidence of bacterial pathogens in blood} cultures from immunocompromised patients

Detection of bacterial pathogens is normally performed in blood cultures, now using automatic incubation/detection systems. Blood is normally regarded as a sterile medium. However, some episodes of septicemia may occur due to occasional microbial contamination, e.g., major purulent surgery, dental extraction etc. Fungal pathogens may be detected in blood both by beta-galactomannan immunoassay, or by DNA diagnostics. Viral infection/reactivation is routinely detected in whole blood or plasma by means of PCR. 
Blood screening for bacterial infections may be an efficient tool of infection monitoring. Blood culture done at a regular interval of at least 5 days. Studies on surveillance blood cultures in HSCT are routinely practicized at many centers. E.g., this approach was tested by for 205 patients admitted for auto- or allo-HSCTs [12]. Bloodstream infection was detected in $14.1 \%$ of these patients, which is at lower limits of previously reported rates (12.5-40\%). Suprisingly, none of the patients who developed bloodstream infection were diagnosed by surveillance blood cultures. Blood cultures taken in presence of clinical infectious symptoms were much more informative. The most common organisms isolated were coagulasenegative staphylococci, 41/84 (49\%) in pure culture and an additional $10(12 \%)$ in mixed cultures. Klebsiella spp. and Enterococci each accounted for 5 episodes (6\%) of positive cultures; Viridans group streptococci accounted for 2 episodes (2.4\%); and the remaining $25 \%$ were caused by different organisms.

In some other countries, the spectrum of cultured bloodborne bacteria is shifted towards Gram-negative microbes, i.e., Pseudomonas aeruginosa, Klebsiella pneumonia, Esherichia coli, Acinetobacter spp, Enterobacter spp. as reported by an Indian team who analyzed data from 653 pediatric cancer patients undergoing chemotherapy [13].

In a Belarus study, the incidence (top-10) of cultivable bacterial pathogens during the early period after HSCT, their culture and identification was assessed with BacT/ALERT-Vitec technique [14]. The following rating of microbial detection was obtained (Table 2), with Klebsiella pneumonia and Escherichia coli. making $>40 \%$ of all clinical microbial isolates.

In immunocompromised patients, herpesviruses, fungal infections, hepatitis B and C are taken into scope.

Table 2. Detection rates for different bacterial pathogens in blood of HSCT patients [14]

\begin{tabular}{|l|l|l|}
\hline Bacterial species & $\begin{array}{l}\text { Absolute } \\
\text { number }\end{array}$ & $\begin{array}{l}\text { Percentage } \\
\text { of total }\end{array}$ \\
\hline Klebsiella pneumonia & 34 & $25.2 \%$ \\
\hline Escherichia coli & 25 & $18.5 \%$ \\
\hline Acinetobacter baumannii & 16 & $11.8 \%$ \\
\hline Pseudomonas aeruginosa & 12 & $8.9 \%$ \\
\hline Stenotrophomonas maltophilia & 1 & $0.7 \%$ \\
\hline Staphylococcus epidermidis & 11 & $8.2 \%$ \\
\hline Staphylococcus spp. & 23 & $17.0 \%$ \\
\hline Staphylococcus hominis & 4 & $3.0 \%$ \\
\hline Staphylococcus haemolyticus & 3 & $2.2 \%$ \\
\hline Streptococcus pneumoniae & 2 & 1.5 \\
\hline Enterococcus faecium & 2 & 1.5 \\
\hline Enterococcus faecalis & 2 & 1.5 \\
\hline
\end{tabular}

A comprehensive randomized analysis of posttransplant infections which occured during 2 years after HSCT was reported by Young et al. [15] being performed in the patients from USA BMT centers. A total of 499 patients were under study exhibiting 1347 infection episodes of severe or life-threatening grade documented in 384 (77\%) patients. $249(81 \%)$ of these patients had received a BM graft and $183 / 250(73 \%)$ had received a PBSC graft, at a cumulative two-year incidence of infections of $80-85 \%$. The majority of these episodes, $810(60 \%)$, were due to bacteria, with a twoyear cumulative incidence of $72.1 \%$ and $62.9 \%$ in BM versus PBSC recipients, respectively $(\mathrm{P}=.003)$. The cumulative incidence of bacterial infections during the first 100 days was $44.8 \%$ for $\mathrm{BM}$ vs. $35.0 \%$ for PBSC $(\mathrm{P}=0.027)$. The infection rates were slightly more often after $\mathrm{BM}$ transplantation than following peripheral PBSCT (Table 3).

\section{Local microbiotes as a source of opportunistic flora}

\section{Skin surface}

Normal skin harbors hundreds of opportunistic or commensal microorganisms including bacteria, fungi and viruses that compose skin microbiome [16]. The skin cell populations (keratinocytes, dermal cells, fibroblast, macrophages etc.) release a lot of protective factors and molecules (antimicrobial peptides etc.), to limit excessive microbial growth and colonization [17]. Therefore, survival of the microorganisms on the skin surface sufficiently depends on their ability to resist the host defense mechanisms [18].

The major fraction is represented by coagulase-negative staphylococci such as S.epidermidis $[19,20]$ as well as more pathogenic S.aureus [21]. Sebaceous glands are colonized by Propionibacterium acne [22]. Candida yeasts also colonize skin surface, being, however, controlled by appropriate defense mechanisms [23]. In immunocompetent organism, these microflora interact with keratinocytes and local immune cells, thus supporting limiting local growth of skin microflora. However, in immunocompromised and elderly patients, the commensal skin staphylococci, Candida yeasts etc. may be isolated from the sites of extradermal opportunistic infections, like catheter- or pacemaker-associated inflammatory conditions [24]. Clinical studies show that all the mentioned skin microflora could be revealed in blood of the immunocompromised patients (see tables 2, 3).

\section{Oral mucosa}

Hundreds microbial and viral species, of them - only up to 5-10 marker microbes, Candida yeasts and viruses (EBV). Dental flora could be revealed in bloodstream, and, especially, in heart valves [25], thus demonstrating a wide opportunity of a distant microbial contamination with opportunistic oral microflora.

Oral mucosa is protected by innate immunity factors, playing a crucial role in the regulation of oral health. E.g., epithelial cells lining oral mucosal surfaces provide not only a physical barrier but also produce different antimicrobial peptides, including human $\beta$-defensins (hBDs), lactoferrin, secretory 
Table 3. Incidence of infectious pathogens revealed over 2 years after allo-HSCT [15]

\begin{tabular}{|l|l|l|}
\hline Organism & Bone marrow transplants, N (\%) & $\begin{array}{l}\text { Peripheral blood stem cell } \\
\text { transplant, N (\%) }\end{array}$ \\
\hline Bacterial infections & $123(82)$ & $101(67)$ \\
\hline Staphylococcus (coagulase negative) & $54(42)$ & $49(40)$ \\
\hline Enterococcus (all species) & $69(52)$ & $54(41)$ \\
\hline Clostridium difficile & $10(9)$ & $30(20)$ \\
\hline Staphylococcus (coagulase positive) & $16(15)$ & $23(19)$ \\
\hline Escherichia (also E. coli) & \multicolumn{2}{|l|}{} \\
\hline Viral infections & $78(61)$ & $81(57)$ \\
\hline Cytomegalovirus (CMV) & $27(25)$ & $27(24)$ \\
\hline Polyomavirus & $16(14)$ & $22(17)$ \\
\hline Herpes Simplex (HSV1, HSV2) & $15(12)$ & $21(15)$ \\
\hline Epstein-Barr Virus (EBV) & $22(19)$ & $13(13)$ \\
\hline Influenza & \multicolumn{2}{|l|}{} \\
\hline Fungal/Parasitic infections & $12(11)$ & $13(12)$ \\
\hline Other (suspected) Fungus & $5(4)$ & $12(10)$ \\
\hline Yeast other than Candida albicans & $6(6)$ & $10(8)$ \\
\hline Candida albicans & $5(5)$ & $6(5)$ \\
\hline Aspergillus fumigatus & $5(4)$ & $2(2)$ \\
\hline Mucormycosis (Zygomycetes, Rhizopus) & $1(1)$ & $2(2)$ \\
\hline Pneumocystis & $1(1)$ & $1(1)$ \\
\hline Toxoplasma & & \\
\hline
\end{tabular}

leukocyte protease inhibitor (SLPI), and various cytokines [26]. Specific IgA's provide specific immune response. There are a lot of oral co-infections revealed in HIV-infected patients, such as human herpesvirus 6 and 8 (HHV-6, HHV-8), herpes simplex virus $1 / 2$ (HSV-1/2), EBV, and human papilloma virus (HPV). Colonization with Candida species is also quite common in these patients. Oral hairy leukoplakia caused by Epstein Barr virus is a typical infection associated with immune suppression [27].

Non-tuberculosis mycobacteria (non-MBT) are also common among oral microflora [28]. When examining healthy persons, the non-MBT DNA was detected in the nostrils of all 10 subjects, in buccal mucosa of 8 subjects, in the oropharynx of 7 subjects, and in the dental plaques of 5 subjects.

\section{Oropharyngeal mucosa}

In a group of 82 patients with head-and-neck cancer treated by chemo/radiotherapy, the authors studied subgingival biofilm samples, oral lavages and whole saliva samples obtained to microbiologically analyze the effects of cancer treatments (1-year follow-up). As compared to surgically treated patients, an increased prevalence of $P$. gingivalis, $T$. forsythia, $S$. mutans and Candida species was observed in the treated areas, thus demonstrating immunosuppressive action of the cytotoxic therapy [29]. Significance of these findings in oncohematology was evaluated by Schuurhuis et al. [30] after cytostatic treatment of 28 leukaemic and 35 auto-HSCT patients. Acute oral foci of infection were found in 2 leukaemic (7\%) and 2 ASCT patients (6\%), and chronic oral foci of infection in 24 leukaemic (86\%) and 22 ASCT patients (63\%). Positive blood cultures with microorganisms potentially originating from the oral cavity occurred in 7 patients during treatment, but did not correlate with development of infectious complications.

Nasopharyngeal area is characterized by interactions between adenoid microorganisms [31]. Adenoid microbiota plays an important role in the development of various infectious and non-infectious diseases of the upper airways, such as otitis media, adenotonsillitis, rhinosinusitis and adenoid hypertrophy. Studies have suggested that adenoids could act as a potential reservoir of opportunistic pathogens. However, previous bacterial surveys of adenoids were mainly culture based and therefore might only provide an incomplete and potentially biased assessment of the microbial diversity. To develop an in-depth and comprehensive understanding of the adenoid microbial communities and test the 'pathogen reservoir hypothesis', we carried out a 16S rRNA based, culture-independent survey of bacterial communities on 67 
human adenoids removed by surgery. Our survey revealed highly diverse adenoid bacterial communities distinct from those of other body habitats. Despite large interpersonal variations, adenoid microbiota shared a core set of taxa and can be classified into at least five major types based on its bacterial species composition.

\section{Broncho-alveolar mucosa}

Colonization of mucosal surfaces with autoflora (cocci, yeast fungi and molds, latent viruses), has an important stimulatory effect on whole-body development of immune responses [32]. However, the opportunistic local microflora in immunocompromised patients may extensively grow on the mucous surfaces in association with more or less severe clinical symptoms, e.g., opportunistic gramnegative bacilli (Enterobacteriaceae, Pseudomonas, Acinetobacter spp.). Moreover, relatively virulent serovars of $\mathrm{M}$. avium complex, like as other non-MBT bacteria, may colonize the bronchial and intestinal mucosal surfaces of healthy individuals in immunocompromised conditions [33]. The same could be found with fungal outgrowth and Toxoplasma activation.

\section{Gastrointestinal tract (GIT)}

Extensive gut microbiota contains hundreds of microbial species of which only few are able to grow on media used in clinical laboratories. The most detectable opportunistic infectious pathogens are: E.coli, C. difficile, Enterococcus fecalis/faecium, etc. Meanwhile, most microorganisms (up to $70 \%$ ) are fastidious or non-culturable species which may be revealed only by DNA or protein diagnostics.

As reviewed by Callejas-Díaz and Gea-Banacloche [34], the C. difficile infection (CDI) is very frequent at early terms after hematopoietic stem cell transplantation (HSCT) - between $6 \%$ and $20 \%$ of HSCT recipients during the first year mostly after allo (allo-HSCT), thus being a promising bacterial marker of intestinal dysbiosis. For diagnostics, molecular testing for the toxin genes by (PCR) is performed, along enzyme immunoassays (EIA). It correlates with worsening of bowel graft versus host disease (GVHD).

Early after cytoreductive therapy one may observe severe damage of chemosensitive intestinal mucosa [35]. Intestinal microflora undergoes sufficient changes within several days after intensive chemotherapy and/or HSCT. At present time, these shifts in microflora subsets are effectively detected by means of multiplex high-throughput PCR followed by sequencing of the obtained genome fragments and computer-assisted differentiation of these genome segments. The mentioned mucosal damage and inflammation is associated with a reduced biodiversity of intestinal microflora developing after HSCT (see a review by [36] Kucher et al., 2017). In turn, altered intestinal microbiota after HSCT is shown to be an important risk factor of severe GVHD [37]. Hence, the interactions between gut microbial antigens and immune cells are enhanced early after cytotoxic chemotherapy.

\section{Gut bacterial translocation: lessons from HIV infection}

A gradually developing immune deficiency in HIV infection, while bearing other pathogenetic features, is known to be associated with a number of concomitant infectious complications (HCV, tuberculosis etc.) and a variety of somatic comorbidities [38] (Currier, Havlir 2005). Opportunistic infections are commonly associated with HIV infection. E.g., some malignant lymphomas in HIV patients may occur due to activation of latent Epstein-Barr virus and, probably, HHV8 [39], like as secondary lymphomas in post-transplant immunocompromised patients. Bacterial opportunistic infections, such as Pneumocystis jiroveci, Toxoplasma gondii, and Mycobacterium avium threaten the patients at CD4+ T cell counts below 200 cells/mcL [40]. However, exact critical levels for CD4+ cells are quite varying. Therefore, a multiplex detection of opportunistic pathogens would be performed, in order to assess real individual degree of clinical immunodeficiency.

In HIV-infection, the intestinal damage and microflora changes are followed by activation of monocytes and residual $\mathrm{T}$ cells, due to the so-called bacterial translocation, i.e., penetration of gut bacterial cell components from injured intestinal wall to bloodstream [41]. The bacterial translocation is registered as endotoxin or soluble monocyte (CD14) antigen detected in blood serum. This "subseptic" condition is recognizable in HIV-infected patients, especially, those receiving suboptimal antiretroviral therapy. According to this opinion, the damaged gut epithelium allows diffusion of bacterial antigens which stimulate monocytes, IL-17 and IL-22-secreting cells.

The mentioned markers of microbial translocation in HIV infection showed some pathogenetic links with quantitative shifts in gut microflora, as shown by next-generation sequencing of bacterial $16 \mathrm{~S}$ rRNAs which identifies hundreds of intestinal microbial species [42]. The analysis of gut microbial diversity showed a more restricted microbiota spectrum, both at baseline and after antiretroviral therapy (ART). The skewed biodiversity of gut flora correlated with decreased CD4 T-cell counts and increased markers of microbial translocation and monocyte activation. Moreover, bacterial lipopolysaccharide (LPS) and soluble CD14 (monocyte antigen) concentrations in blood plasma are shown to predict mortality and disease progression in subjects with HIV infection [41]. Intestinal epithelial damage and altered gut microflora in allogeneic HSCT are also well proven [36]. Hence, the markers of bacterial translocation may be potentially effective in diagnostics of any immune deficiency, aiming to evaluate possible damage to the gut mucosa and altered immune response after HSCT.

\section{Urine and urogenital ways}

The urine is sterile in healthy children. Normally, the urinary epithelium is protected by specific antibacterial factors, e.g., Tamm-Horsfall protein, lactoferrin, defensins etc [43]. With age, however, the urinary system is colonized in ascending manner with microflora from skin (Klebsiella pneumoniae, Pseudomonas aeruginosa, Staphylococci, Candida) and gut (Escherichia coli, Enterobacter, Enterococcus, Proteus mirabilis). However, hematogenic infections are also possible due to Staph. aureus, Haemophilus influenza etc., thus causing chronic cystitis and pyelitis often complicated by infectious kidney stone formation [44].

Protozoic infections, e.g.., Toxoplasma gondii, may be also revealed in urogenital ways over $1^{\text {st }}$ month after HSCT [45], 
with rapid disappearance from urine cells upon hematopoiesis reconstitution.

Early after hematopoietic transplantation, hemorrhagic cystitis is developing in most cases, mainly, due to urothelial damage by toxic cytostatic treatment. Meanwhile, activation of BK and JC viruses (latent polyomaviruses in urothelial cells) are additional markers of hemorrhagic cystitis at the terms of 1-2 months which are found in urine at early terms post HSCT [46].

Catheter-associated urinary infection is a special issue in immunodeficient patients. It may be caused by P.mirabilis migrating from gut [47], or other urease-positive microbes migrating, mainly, from skin. Multiple bacterial species co-exist in microbial biofilms growing on the bladder epithelium and in catheter lumen [48].

\section{Mixed infections in immunocom- promised patients}

\section{Bacterial/fungal co-infections}

Combined infections with bacterial and/or fungal agents after cytotoxic treatment in post-transplant patients were described in many works. However, the mechanisms of their simultaneous emergence are not clear yet. Acute failure of protective immune mechanisms could be the most plausible explanation for these posttransplant conditions. Moreover, multiple occurence of several pathogens in a single biological sample (i.e., blood, urine, or saliva) in HSCT patients may be promoted by a symbiotic microbial growth, thus causing a co-infection. Polymicrobial complexes grown as biofilms are regularly observed in local infections, such as dental caries and parodontitis, otitis media, diabetic foot wounds etc. [49]. Similar growth of bacterial associations is typical to blood catheter-associated infections, or urinary catheter contamination. Hence, bacterial co-infections are not rare and should be detected in HSCT setting.

The incidence of bacterial and/or fungal infections was assessed in a group of 901 stem cell transplant recipients [50]. Of them, 237 patients (27\%) had microbiologically documented microorganisms isolated, including 34 patients (14\%) simultaneously infected with multiple microorganisms. The co-infected patients seem to be at an increased risk for aGvHD and delayed graft functioning.

The same workers evaluated infection by Clostridium diffcile, a common opportunistic microbe, and its association with other infectious agents [51]. Among 822 consecutive autologous and allogeneic HCST recipients, 85 cases (10.3\%) of C.difficile-associated disease were identified. Significant associations were found between C.difficile detection, and neutropenic fever, as well as with bacterial coinfection, and presence of vancomycin-resistant Enterococcus faecium (VRE) colonization. Allo-HSCT patients with C.difficile-associated disease showed higher rates of severe gastrointestinal aGvHD.

\section{Viral co-infections}

Combined post-transplant viral co-infections are also quite common, thus suggesting their treatment by injection of the virus-specific immune lymphocytes [52]. Simultaneous activation of several common endogenous viruses was shown by a multiplex PCR system for 13 common viral species in some patients before allo-HSCT, while being increased within $1^{\text {st }}$ month after transplant [53].

Simultaneous co-activation of herpesviruses is a regular finding. E.g., in a Polish study [54] 142 allo-HSCT recipients were tested for 3 herpesviruses (CMV, HHV-6 and HHV-7) for the first 3 months. Reactivation of more than one virus was identified in $31 \%$ of analysed patients, with CMV being most common, thus increasing risk of specific complications posttransplant.

In a recent study by Koskenvuo et al. [55] the authors studied 23 viruses in 53 paediatric patients up to 3 months after allo-HSCT. Interestingly, polyomaviruses predominated over herpesviruses thus showing their common incidence in the immunodeficient cohort. Of them, 13 patients (25\%) had viraemias by multiple viruses. Presence of viral co-infections was significantly associated with aGvHD and steroid use, the factors known to suppress immune functions.

There are specific combinations of certain viral species in post-HSCT patients. According to results obtained by Jeulin et al. [56], HHV6 infection did not correlate with CMV, HSV, EBV. Meanwhile, adenovirus infection and HHV-6 activation seemed to be related in their posttransplant replication.

\section{Mixed infectious pathogens}

A large meta-analysis was performed by Klein et al. [57] based on a systematic search of different medical databases on influenza virus-associated infections. It covered 27 studies including 3215 participants, with widely varying coinfection rates ranging from $2 \%$ to $65 \%$. Most common coinfecting species were S. pneumoniae and Staph. aureus, which accounted for $35 \%$ and $28 \%$ of infections followed by P.aeruginosa, S. pyogenes, H. influenzae,.K. pneumoniae, and M. pneumoniae.

A study by Chebotkevitch et al. [58] has revealed that cytostatic treatment was associated with higher CMV and EBV activation rates if the patients had concomitant bacterial infections, thus confirming a potentially common reason for mixed-type infections in this cohort (Table 5).

To confirm a need for multiplex studies of infectious agents in local samples, we would like to refer our previous study concerning incidence of different opportunistic pathogens in the tissues of heart valves surgically obtained from cardiosurgery patients subjected to valve replacement (Table 4). Of course, this group comprised patients with a story of septic episodes before the valve disorder had developed. However, a number of DNA species (both microbes and viruses) was revealed in $72 \%$ of the heart valves from the patients with septic endocarditis thus showing their high rates of exposure to infectious agents. Moreover, a number of the samples tested has shown positivity for both bacterial and herpesvirus DNA, thus suggesting high probability of mixed valves contamination from the circulating blood. The enlisted microbial species may originate from skin (Staphylococci, Streptococci, Candida spp), gut (E.Coli), oral cavity (P.Gingivalis, Actinobacillus actinomycetemcomitans, T.Forsythus), then 
being translocated via bloodstream at any time of transient bacteremia.

Similar data on heart valve contamination by multiple bacteria were obtained by Miller et al. [59] using broad-range 16S rDNA PCR and Sanger sequencing on a specific fragment of ribosomal DNA extracted from $\mathrm{HV}$ tissues.

Hence, the existing diagnostic approach to detection of mixed microbial and viral infections in post-transplant patients seems to be rational and feasible. Multiplicity of infectious agents should then correlate with grade of anti-infectious response and risk of severe GvHD. This issue may be resolved by detection of group-specific microbial and viral markers.

\section{Multiple infections and post-transplant mortality risk}

Some previous results suggest increased mortality of HSCT patients with diagnosed multiple bacterial infections. E.g., Trifilio et al. [50] have reviewed clinical and laboratory data of 901 HSCT recipients (675 auto- and 226, allo-HSCTs). When studying different biomaterials, the authors have identified 179 patients with proven monomicrobial infection and 59 patients (24\%) with multiple microorganisms, of which $34(14 \%)$ were classified as polymicrobial infection (PI), and $25(10 \%)$ as multiple distinct episodes of infection (MDE).

Table 4. Incidence of infectious pathogens in heart valves excised from the patients with septic endocarditis [25]

\begin{tabular}{|l|l|l|}
\hline Pathogen species & Number of positives & \% of total specimen number $(\mathbf{n}=91)$ \\
\hline Staph. Spp. & 42 & 46,2 \\
\hline Streptoc. Spp & 30 & 33 \\
\hline Candida alb. & 8 & 8,8 \\
\hline E.coli VT-L1 & 5 & 5,5 \\
\hline E.coli VT-L2 & 6 & 6,6 \\
\hline E.coli H7 & 0 & 0 \\
\hline P.Gingivalis & 3 & 3,3 \\
\hline Actinobacillus actinomycetemcomitans & 6 & 6,6 \\
\hline T.Forsythus & 4 & 4,4 \\
\hline HSV l:2 & 20 & 22 \\
\hline CMV & 9 & 9,9 \\
\hline JБB & 13 & 14,3 \\
\hline Ureapl Spp. & 0 & 0 \\
\hline Chlam trachoma & 0 & 0 \\
\hline Mycopl hominis & 17 & 18,7 \\
\hline
\end{tabular}

Table 5. Incidence of herpesvirus DNA in leukemia patients with/without bacteremia [58]

\begin{tabular}{|l|l|l|l|l|}
\hline \multirow{2}{*}{ Samples under study } & \multicolumn{4}{|c|}{ Herpesvirus type, absolute (\%) } \\
\cline { 2 - 5 } & CMV & HSV 1/2 & HHV6 & EBV \\
\hline Leukemia patients n=437 & $21(4.8 \%)$ & $13(3 \%)$ & $48(11 \%)$ & $109(24.9 \%)$ \\
\hline $\begin{array}{l}\text { Leukemia patients with } \\
\text { proven bacterial blood } \\
\text { contamination n=21 }\end{array}$ & $8(38.1 \%)$ & $1(4.8 \%)$ & $2(9.5 \%)$ & $12(51.1 \%)$ \\
\hline $\mathrm{P}$ & $<0.05$ & $>0.05$ & $>0.05$ & $<0.05$ \\
\hline
\end{tabular}


There were no significant connections between the infection multiplicity, and age, gender, diagnosis, time to engraftment, response to therapy, etc. However, overall mortality at day +100 post transplant was higher in patients with multiple infectious episodes ( $\mathrm{P}=0.02$ in the Kaplan-Meier analysis). These patients also proved to be at an increased risk for acute GVHD and graft failure. In particular, early and frequently presenting Gram-negative infections, and fungal (mostly, Candida) infections were associated with high mortality rates.

Common endogenous viruses (4 herpesviruses, BK polyomavirus, and adenovirus) were studied in allo-HSCT setting by Hill et al. (2017) [60]. The workers performed weekly quantitative PCR of blood plasma for viral DNA from 404 allo-HSCT patients. CMV was the most common virus (65\% of patients), followed by BKV (54\%), HHV-6B (46\%), AdV (10\%), and EBV (9\%). CMV, BKV, and HHV-6B were the viruses most frequently seen in combination. Detection of multiple viruses until day +100 was quite common: $90 \%$ had $\geq 1,62 \%$ had $\geq 2,28 \%$ had $\geq 3$, and $5 \%$ had 4 or 5 viruses. Acute GVHD grade 3-4 was associated with detection of $\geq 2$ viruses. Myeloablative conditioning was associated with a significantly higher risk for $\geq 3$ and $\geq 4$ viruses. Age $\leq 21$ was associated with detection of $\geq 4$ viruses (aHR 2.65). In general, activation of multiple dsDNA viruses had a dose-dependent association with increased mortality after allo-HSCT, being independent on immune reconstitution rates and acute GVHD. These data suggest opportunities to improve outcomes with better preventive antiviral strategies.

\section{Prototype test systems for detec- tion of multiple marker pathogens}

1. Rapid blood cultures performed by several approved systems, i.e., BD BACTEC, BacT/ALERT 3D, VersaTREK and similar automated devices. They use standard aerobic and anaerobic broth media for samples and provide results within few days and even hours. The data are read by colorimetry, fluorimetry, or redox changes of the media [61]. This approach allows to obtain clinical isolates for the most opportunistic bacteria listed in Table 1.
2. Manual and automated multiplex PCR was proposed by several firms, e.g., Roche, Interlabservice. To systhematize this search, a number of diagnostic panels are developed for detection of commensal/opportunistic infectious pathogens. An example of such multiplex diagnostics was developed by Roche (SeptiFast), as shown in Table 6 .

Appropriate systemic review and meta-analysis of SeptiFast diagnostic kits in septic patients was performed by Chang et al. (2013) [62]. A total of 34 studies enrolling 6012 patients of suspected sepsis were included. In general, sensitivity and specificity estimates for combined bacteremia and fungemia outcome were 0.75 , and 0.92 , respectively.

However, the mentioned multiplex PCR system covers only some opportunistic bacteria and fungi, thus missing viruses which are prone for reactivation post-HSCT. Mixed bacterial/viral PCR assays are still under development. E.g., such multiplex real-time PCR was recently used in order to evaluate CNS infection in infants [63].

Moreover, a diagnostic panel for combined opportunistic infections should include multiplex system for detection of infectious agents in the given local sample (urine, BAL, spinal liquor etc. Such panel should detect the most common bacterial, fungal and viral pathogens (up to 15-20), in order to detect immune deficiency and its degree (by the number of positive findings per sample). It may be based either on multiplex PCR, or on microarray detection mode.

3. A more general, genus-specific PCR assays have been developed, e.g., in Russia. These multiplex real-time PCR systems are aimed for diagnostics of vaginal or gut dysbiosis (resp., Femoflor, and ColonoFlor) detecting up to 16 microbial classes in appropriate biological samples. The ratios of different microbiota members in complex biological materials are calculated, thus allowing quantify the balance of typical microbiota species in, urogenital or intestinal specimens.

4. Looking for endotoxin and surrogate markers in blood plasma, a search for microbial translocation via bloodstream (endotoxin, sCD14) may be applied, using the strategy previously used for studies of HIV infection.

Table 6. The SeptiFast diagnostic panel (multiplex PCR detection)

\begin{tabular}{|l|l|l|}
\hline Gram-negative bacteria & Gram-positive bacteria & Fungal pathogens \\
\hline Escherichia coli & Staphylococcus aureus & Candida albicans \\
\hline Klebsiella pneumoniae & Coagulase-negative Staphylococci & Candida tropicalis \\
\hline Klebsiella oxytoca & Streptococcus pneumoniae & Candida parapsilosis \\
\hline Serratia marcescens & Streptococcus spp. & Candida krusei \\
\hline Enterobacter cloacae & Enterococcus faecium & Candida glabrata \\
\hline Enterobacter aerogenes & Enterococcus faecalis & Aspergillus fumigatus \\
\hline Proteus mirabilis & & \\
\hline Pseudomonas aeruginosa & & \\
\hline Acinetobacter baumannii & & \\
\hline Stenotrophomonas maltophilia & & \\
\hline
\end{tabular}


5. Detection of total microbial contamination in blood and other normally sterile media. One may use currently developed methods for detection of total microbial DNA, or specific genes for detecting Gram+ and Gram-negative microorganisms [64]. However, most workers use in-house systems for these studies, thus being allowed for research only.

6. Moreover, some antigenic tests are commonly applied in order to detect opportunistic fungal invasions (betagalactomannan) in blood and bronchoalveolar lavage.

A search for mixed infections in posttransplant patients should make diagnostics of immune deficiency more adapted for the needs of medical practice. Detection of severe-grade immune failure may justify usage of some known treatments in order to enhance innate and adaptive immunity in the patient. E.g., detection of polymicrobial infection may be a indication for usage of immunostimulatory cytokines and hemopoietic growth factors in oncohematological patients [65]. Moreover, finding of mixed infection in the patient could be a proven indication for G-SF-primed granulocyte transfusions, at least during posttransplant febrile neutropenia [66].

\section{Conclusion}

1) A variety of microbes and viruses normally exists on skin and mucosal surfaces of gastrointestinal and urogenital tract.

2) In cases of immune deficiency of either type, some of the microorganisms extend or activate at other body sites, thus causing opportunistic infections, e.g., interstitial skin abscesses, pneumonias, septicemias, catheter-associated infections. Activation of endogenous viruses (e.g. CMV) is shown to cause local lesions of different organs and tissues.

3) Hence, multiplicity assessment of common infectious biomarkers (bacteria, fungi and viruses) in blood and other unusual body sites may be used to assess grade of immune deficiency in posttransplant patients at early (cytopenic) and late time periods (chronic immune deficiency).

4) In view of low culture efficiency for many microorganisms in humans, the panels for common marker infections are developed which will reflect grade of immune deficiency. It could be based on express bacterial diagnostics, but, mostly, on multiplex real-time PCR of distinct pathogenic species. SeptiFast could be applied to these purposes, with addition of some multiplex PCR tests for detection of viruses, in order to detect combined viral infections. Some antigenic markers (e.g., endotoxin, beta-galactomannan) could be also screened in the HSCT patients, being complementary to the battery of microbiological tests for specifying grade of the patients' immunodeficiency.

\section{References}

1. Pankratova OS, Chukhlovin AB. Time course of immune recovery and viral reactivation following hematopoietic stem cell transplantation. Cell Ther Transplant. 2016; 5(4):32-43.

2. Podgorny PJ, Pratt LM, Liu Y, Dharmani-Khan P, Luider J, Auer-Grzesiak I, Mansoor A, Williamson TS, Ugarte-Torres A, Hoegh-Petersen M, Khan FM, Larratt L, Jimenez-Zepeda VH, Stewart DA, Russell JA, Daly A, Storek J. Low counts of B cells, natural killer cells, monocytes, dendritic cells, basophils, and eosinophils are associated with postengraftment infections after allogeneic hematopoietic cell transplantation. Biol Blood Marrow Transplant. 2016;22(1):37-46.

3. Maschmeyer G, Ljungman P. Infections in Hematopoietic Stem Cell Transplant Recipients. In: A. Safdar (ed.), Principles and Practice of Cancer Infectious Diseases, Current Clinical Oncology, 17, Springer Science+Business Media, LLC 2011. P.17-25.

4. Hu B, Mohty M, Savani BN. Common non-seasonal viral infections after hematopoietic stem cell transplantation. Hematologie 2013; 19: 268-278.

5. Ullmann AJ, Schmidt-Hieber M, Bertz H, Heinz WJ, Kiehl M, Krüger W, Mousset S, Neuburger S, Neumann S, Penack O, Silling G, Vehreschild JJ, Einsele H, Maschmeyer $\mathrm{G}$ on behalf of the Infectious DiseasesWorking Party of the German Society for Hematology and Medical Oncology (AGIHO/DGHO) and the DAG-KBT (German Working Group for Blood and Marrow Transplantation). Infectious diseases in allogeneic haematopoietic stem cell transplantation: prevention and prophylaxis strategy guidelines. Ann Hematol. 2016;95(9):1435-1455.

6. Robinson PD, Lehrnbecher T, Phillips R, Dupuis LL, Sung L. Strategies for Empiric Management of Pediatric Fever and Neutropenia in Patients With Cancer and Hematopoietic Stem-Cell Transplantation Recipients: A Systematic Review of Randomized Trials. J Clin Oncol. 2016;34(17):2054-2060.

7. Chen C-S, Boeckh M, Seidel K, Clark JG, Kansu E, Madtes DK, Wagner JL, Witherspoon RP, Anasetti C, Appelbaum FR, Bensinger WI, Deeg HJ, Martin PJ, Sanders JE, Storb R, Storek J, Wade J, Siadak M, Flowers MED, Sullivan KM. Incidence, risk factors, and mortality from pneumonia developing late after hematopoietic stem cell transplantation. Bone Marrow Transplantation. 2003;32:515-522.

8. Bodey GP. Unusual presentations of infection in neutropenic patients. Int J Antimicrob Agents. 2000;16(2):93-95.

9. Avigan D, Pirofski L-A, Lazarus HM.Vaccination against infectious disease following hematopoietic stem cell transplantation. Biol Blood Marrow Transplant. 2001;7:171-183.

10. Marty FM, Rubin RH. The prevention of infection posttransplant: the role of prophylaxis, preemptive and empiric therapy. Transplant Int. 2006;19(1):2-11.

11. Averyanova M.Yu., Vavilov V.N., Bondarenko S.N., Uspenskaya O.S., Stancheva N.V., Semenova E.V., Volkova A.G., Smirnov B.I., Baranova I.B., Zubarovskaya L.S., Klimko N.N., Afanasyev B.V. Bacterial infections in pediatric and 
adolescent recipients in allogeneic hematopoietic stem cell transplantation: etiology, structure, risk factors. Journal of Infectology, 2013, 5(1): 35-43 (In Russian).

12. Ghazal SS, Stevens MP, Bearman GM, Edmond MB. Utility of surveillance blood cultures in patients undergoing hematopoietic stem celltransplantation. Antimicrobial Resistance and Infection Control 2014, 3:20.

13. Reddy R, Pathania S, Kapil A, Bakhshi S. Review of spectrum and sensitivity of bacterial bloodstream isolates in children with malignancy: A retrospective analysis from a single center. Ind J Cancer. 2014; 51(4): 425-427.

14. Stoma I, Karpov I, Milanovich N, Uss A, Iskrovi. Risk factors for mortality in patients with bloodstream infections during the pre-engraftment period after hematopoietic stem cell transplantation. Blood Res. 2016; 51(2):102-106.

15. Young JAH, Logan BR, Wu J, Wingard JR, Weisdorf DJ, Mudrick C, Knust K, Horowitz MM, Confer DL, Dubberke ER, Pergam SA, Marty FM, Strasfeld LM, Brown JM, Langston AA, Schuster MG, Kaul DR, Martin SI, Anasetti C for the BMT CTN Trial 0201. Infections following transplantation of bone marrow or peripheral-blood stem cells from unrelated donors. Biol Blood Marrow Transplant. 2016; 22(2):359-370.

16. Schommer NN, Gallo RL. Structure and function of the human skin microbiome. Trends Microbiol. 2013;21(12):660668.

17. Gallo RL, Nakatsuji T. Microbial symbiosis with the innate immune defense system of the skin. J Invest Dermatol. 2011;131(10):1974-1980.

18. Roth RR, James WD. Microbiology of the skin: resident flora, ecology, infection. J Am Acad Dermatol. 1989;20(3):367-390.

19. Widerström M, Wiström J, Sjöstedt A, Monsen T. Coagulase-negative staphylococci: update on the molecular epidemiology and clinical presentation, with a focus on Staphylococcus epidermidis and Staphylococcus saprophyticus. Eur J Clin Microbiol Infect Dis. 2012;31(1):7-20.

20. Nguyen TH, Park MD, Otto M. Host response to Staphylococcus epidermidis colonization and infections. Front Cell Infect Microbiol. 2017 Mar 21;7:90. doi: 10.3389/ fcimb.2017.00090. eCollection 2017.

21. Guerra FE, Borgogna TR, Patel DM, Sward EW, Voyich JM. Epic immune battles of history: neutrophils vs. Staphylococcus aureus. Front Cell Infect Microbiol. 2017 Jun 30;7:286. doi: 10.3389/fcimb.2017.00286. eCollection 2017.

22. Christensen GJ, Brüggemann H. Bacterial skin commensals and their role as host guardians. Benef Microbes. 2014;5(2):201-215.

23. Kühbacher A, Burger-Kentischer A, Rupp S. Interaction of Candida Species with the Skin. Microorganisms. 2017 Jun 7;5(2). pii: E32. doi: 10.3390/microorganisms5020032.

24. Da Costa A, Lelièvre H, Kirkorian G, Célard M, Chevalier P, Vandenesch F, Etienne J, Touboul P. Role of the preaxillary flora in pacemaker infections: a prospective study. Circulation. 1998 ;97(18):1791-1795.
25. Zhirekhina OV, Chukhlovin AB, Sysoev KA, Gritsenko VV, Totolian AA. Detection of infectious agents in heart valves during endocarditis using PCR technique. Zh Mikrobiol Epidemiol Immunobiol. 2008; 4:96-98 (In Russian).

26. Nittayananta W, Tao R, Jiang L, Peng Y, Huang Y. Oral innate immunity in HIV infection in HAART era. J Oral Pathol Med. 2016; 45(1):3-8.

27. Reichart PA. Infections of the oral mucosa II. Bacterial, mycotic and viral infections. Mund Kiefer Gesichtschir. 1999 Nov;3(6):298-308. (In German)

28. Macovei L, McCafferty J, Chen T, Teles F, Hasturk H, Paster BJ, Campos-Neto A.. The hidden 'mycobacteriome' of the human healthy oral cavity and upper respiratory tract. J Oral Microbiol. 2015; 7: 10.3402/jom.v7.26094.

29. Schuurhuis JM, Stokman MA, Witjes MJ, Langendijk JA, van Winkelhoff AJ, Vissink A, Spijkervet FK. Head and neck intensity modulated radiation therapy leads to an increase of opportunistic oral pathogens. Oral Oncol. 2016;58:32-40.

30. Schuurhuis JM, Span LF, Stokman MA, van Winkelhoff AJ, Vissink A, Spijkervet FK. Effect of leaving chronic oral foci untreated on infectious complications during intensive chemotherapy. Br J Cancer. 2016;114(9):972-978.

31. Ren T, Glatt DU, Nguyen TN, Allen EK, Early SV, Sale M, Winther B, Wu M. 16S rRNA survey revealed complex bacterial communities and evidence of bacterial interference on human adenoids. Environ Microbiol. 2013;15(2):535-547.

32. Tlaskalová-Hogenová H, Tucková L, Lodinová-Zádniková R, Stepánková R, Cukrowska B, Funda DP, Striz I, Kozáková H, Trebichavský I, Sokol D, Reháková Z, Sinkora J, Fundová P, Horáková D, Jelínková L, Sánchez D. Mucosal immunity: its role in defense and allergy. Int Arch Allergy Immunol. 2002;128(2):77-89.

33. Collins FM. Mycobacterial disease, immunosuppression, and acquired immunodeficiency syndrome. Clin Microbiol Rev. 1989; 2(4):360-377.

34. Callejas-Díaz A, Gea-Banacloche JC. Clostridium difficile: deleterious impact on hematopoietic stem cell transplantation. Curr Hematol Malig Rep. 2014;9(1):85-90.

35. Peterson DE, Cariello A. Mucosal damage: a major risk factor for severe complications after cytotoxic therapy. Semin Oncol. 2004;31(3 Suppl 8):35-44.

36. Kucher MA, Goloschapov OV, Moiseev IS, Afanasyev BV. Fecal microbiota transplantation as a method to treat complications after hematopoietic stem cell transplantation. Cell Ther Transplant. 2017, 6(1): 20-29.

37. Shono Y, Docampo MD, Peled JU, Perobelli SM, Jenq RR. Intestinal microbiota-related effects on graft-versus-host disease. Int J Hematol. 2015;101(5):428-437.

38. Currier JS, Havlir DV. Complications of HIV disease and antiretroviral therapy. Top HIV Med. 2005;13(1):16-23.

39. Navarro WH, Kaplan LD. AIDS-related lymphoproliferative disease. Blood. 2006; 107(1): 13-20. 
40. Hammer SM. Clinical practice. Management of newly diagnosed HIV infection. N Engl J Med. 2005;353(16):17021710 .

41. Tincati C, Douek DC, Marchetti G. Gut barrier structure, mucosal immunity and intestinal microbiota in the pathogenesis and treatment of HIV infection. AIDS Res Ther. 2016 Apr 11;13:19. doi: 10.1186/s12981-016-0103-1. eCollection 2016.

42. Nowak P, Troseid M, Avershina E, Barqasho B, Neogi U, Holm K, Hov JR, Noyan K, Vesterbacka J, Svärd J, Rudi K, Sönnerborg A. Gut microbiota diversity predicts immune status in HIV-1 infection. AIDS. 2015; 29(18):2409-18.

43. Zasloff M. Antimicrobial peptides, innate immunity, and the normally sterile urinary tract. J Am Soc Nephrol 2007; 18(11): 2810-2816.

44. Miano R, Germani S, Vespasiani G. Stones and urinary tract infections. Urol Int 2007;79 [Suppl 1]:32-36.

45. Chukhlovin AB, Zubarovskaya LS, Bondarenko SN, Eismont YuA, Semenov AV, Vladovskaya MD, Totolyan Areg A, Afanasyev BV. Activation of Toxoplasma gondii infection after allogeneic transplantation of haematopoietic stem cells: dependence on time of transplantation and serological status of the patients. Infect Immunity. 2014, 4(4):382-386 (In Russian).

46. Chukhlovin AB, Eismont YuA, Vavilov VN, Zubarovskaya LS, Afanasyev BV. Time- and sample-dependent differences in polyomavirus incidence following hematopoietic stem cell transplantation. Cell Ther Transpl 2016; 5(1):26-30.

47. Drzewiecka D. Significance and roles of Proteus spp. bacteria in natural environments. Microb Ecol. 2016;72:741758.

48. Musk DJ Jr, Hergenrother PJ. Chemical countermeasures for the control of bacterial biofilms: effective compounds and promising targets. Curr Med Chem 2006; 13(18): 2163-2177

49. Peters BM, Jabra-Rizk MA, O’May GA, Costerton JW, Shirtliff ME. Polymicrobial interactions: impact on pathogenesis and human disease. Clin Microbiol Rev. 2012;25(1):193-213.

50. Trifilio SM, Pi J, Mehta J. Changing epidemiology of Clostridium difficile-associated disease during stem cell transplantation. Biol Blood Marrow Transplant. 2013;19(3):405-409.

51. Trifilio S, Zhou Z, Fong JL, Zomas A, Liu D, Zhao C, Zhang J, Mehta J. Polymicrobial bacterial or fungal infections: incidence, spectrum of infection, risk factors, and clinical outcomes from a large hematopoietic stem cell transplant center. Transpl Infect Dis. 2015;17(2):267-274.

52. Sutrave G, Blyth E, Gottlieb DJ. Cellular therapy for multiple pathogen infections after hematopoietic stem cell transplant. Cytotherapy. 2017. pii: S1465-3249(17)30657-6. doi: 10.1016/j.jcyt.2017.07.012.

53. Inazawa N, Hori T, Hatakeyama N, Yamamoto M, Yoto Y, Nojima M, Suzuki N, Shimizu N, Tsutsumi H. Large-scale multiplex polymerase chain reaction assay for diagnosis of viral reactivations after allogeneic hematopoietic stem cell transplantation. J Med Virol. 2015;87(8):1427-1435.

54. Dzieciatkowski T, Tomaszewska A, Przybylski M, Rusicka P, Basak GW, Jedrzejczak WW, Wroblewska M, Halaburda K. Analysis of the shedding of three $\beta$-herpesviruses DNA in Polish patients subjected to allogeneic hematopoietic stem cell transplantation: Six-year follow up. J Clin Virol. 2016;76:30-35.

55. Koskenvuo M, Rahiala J, Sadeghi M, Waris M, Vuorinen T, Lappalainen M, Norja P, Toppinen M, Saarinen-Pihkala U, Allander T, Söderlund-Venermo M, Hedman K, Ruuskanen $\mathrm{O}$, Vettenranta K. Viremic co-infections in children with allogeneic haematopoietic stem cell transplantation are predominated by human polyomaviruses. Infect Dis (Lond). 2017;49(1):35-41.

56. Jeulin H, Agrinier N, Guery M, Salmon A, Clement L, Bordigoni P, Venard V. Human herpesvirus 6 infection after allogeneic stem cell transplantation: incidence, outcome, and factors associated with HHV-6 reactivation. Transplantation 2013;95: 1292-1298.

57. Klein EY, Monteforte B, Gupta A, Jiang W, May L, Hsieh $\mathrm{YH}$, Dugas A. The frequency of influenza and bacterial coinfection: a systematic review and meta-analysis. Influenza Other Respir Viruses. 2016;10(5):394-403.

58. Chebotkevich VN, Bessmeltsev SS, Kiseleva EE, Stizhak NP, Kaytandzhan EI, Burylev VV. Bloodstream infections and herpesvirus activation following intensive chemotherapy of adult oncohematological patients. Cell Ther Transplant. 2016; 5(4):21-31.

59. Miller RGH, Chow B, Pillai D, Church D. Development and evaluation of a novel fast broad-range 16S ribosomal DNA PCR and sequencing assay for diagnosis of bacterial infective endocarditis: multi-year experience in a large $\mathrm{Ca}$ nadian healthcare zone and a literature review. BMC Infectious Diseases. 2016. 16:146

60. Hill JA, Mayer BT, Xie H, Leisenring WM, Huang ML, Stevens-Ayers T, Milano F, Delaney C, Sorror ML, Sandmaier BM, Nichols G, Zerr DM, Jerome KR, Schiffer JT, Boeckh M. The cumulative burden of double-stranded DNA virus detection after allogeneic HCT is associated with increased mortality. Blood. 2017;129(16):2316-2325.

61. Opota O, Croxatto A, Prod'hom G, Greub G. Blood culture-based diagnosis of bacteraemia: state of the art. Clin Microbiol Infect 2015; 21: 313-322.

62. Chang S-S, Hsieh W-H, Liu T-S, Lee S-H, Wang C-H, et al. Multiplex PCR system for rapid detection of pathogens in patients with presumed sepsis - a systemic review and meta-analysis. PLoSONE (2013) 8(5): e62323. doi:10.1371/ journal.pone.0062323

63. Tann CJ, Nkurunziza P, Nakakeeto M, Oweka J, Kurinczuk JJ, Were J, Nyombi N, Hughes P, Willey BA, Elliott AM, Robertson NJ, Klein N, Harris KA.Prevalence of bloodstream pathogens is higher in neonatal encephalopathy cases vs. controls using a novel panel of real-time PCR assays. PLoSONE. 2014;9(5):e97259. doi: 10.1371/journal. pone.0097259. 
64. Wu YD, Chen LH, Wu XJ, Shang SQ, Lou JT, Du LZ, Zhao ZY. Gram stain-specific-probe-based real-time PCR for diagnosis and discrimination of bacterial neonatal sepsis. J Clin Microbiol. 2008;46(8):2613-9.

65. Heuser M, Ganser A, Hoelzer D. The hematopoietic growth factors in acute leukemia: a European perspective. Cancer Treat Res. 2011;157:339-362.

66. Rutella S, Pierelli L, Sica S, Serafini R, Chiusolo P, Paladini U, Leone F, Zini G, D’Onofrio G, Leone G, Piccirillo N. Efficacy of granulocyte transfusions for neutropenia-related infections: retrospective analysis of predictive factors. Cytotherapy. 2003;5(1):19-30. 


\title{
0ппортунистическая микрофлора в необычных местах: маркерные патогены при тяжелом посттрансплантационном иммунодефиците
}

\author{
Алексей Б. Чухловин ${ }^{1}$, Ольга С. Панкратова ${ }^{2}$ \\ НИИ детской онкологии, гематологии и трансплантологии им. Р. М. Горбачевой, Первый Санкт-Петербургский \\ государственный медицинский университет им. И. П. Павлова, Санкт-Петербург, Россия

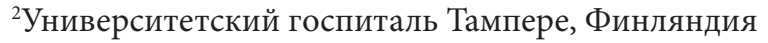

\section{Резюме}

Ранний и тяжелый иммунодефицит развивается после циторедуктивной терапии злокачественных новообразований, особенно после кондиционирующей терапии и трансплантации гемопоэтических стволовых клеток (ТГСК). Восстановление иммунного ответа после трансплантации происходит медленно, особенно в субпопуляциях лимфоцитов. В более поздние сроки иммуносупрессивные препараты способствуют поддержанию состояния иммунного дефицита. Поэтому после ТГСК отмечается активация различных эндогенных инфекций. В большинстве случаев инфекционные осложнения здесь вызываются оппортунистическими микроорганизмами (бактериями, грибами или вирусами), которые в норме заселяют кожные покровы, слизистые и др.). После трансплантации, их пролиферация и миграция может возникать в зонах, которые в норме не вовлечены в инфекционный процесс (сосудистый кровоток, бронхоальвеолярные зоны, мочевые пути, дермальные структуры кожи, лимфоузлы и др.). Таким образом, ранняя посттрансплантационная активация латентных патогенов может определяться в периферической крови, спинномозговой жидкости, бронхоальвеолярных смывах, ротовой жидкости, моче и других биологических материалах, которые в норме защищены иммунными факторами. Число видов инфекционных агентов у данного пациента также коррелирует с более высокой смертностью трансплантационных больных.

В связи с этим, диагностика обычно применяемых маркеров иммунодефицита после интенсивной циторедуктивной терапии может быть дополнена выявлением оппортунистических инфекций в тех биоматериалах, которые обычно не инфицированы ими (периферическая кровь, ротовая жидкость, моча) а также на пораженных слизистых (мокрота, бронхиальные смывы, спинномозговая жидкость). Разработаны несколько валидированных диагностических панелей, основанные, главным образом, на мультиплексной ПЦР для того, чтобы выявить и определить число маркерных микроорганизмов (вирусов, грибов и бактерий) у пациента. Их можно применять для более точной оценки глубины иммунного дефицита.

\section{Ключевые слова}

Циторедуктивная терапия, иммунодефицит, бактерии, вирусы, активация, экспансия, множественные инфекции, маркерные микроорганизмы. 